\title{
VÄITÖKSET
}

\section{Ikääntyneiden aikuisten toimijuus kuntoutuksessa}

\section{Ovatko ikääntyneet aikuiset kuntoutuksen ja aikuiskasvatustieteen ulkopuolella?}

Nykyistä kuntoutusjärjestelmää ei ole rakennettu harmaantuvaa Suomea varten. Kuntoutuksen toteutus, tutkimus ja rahoitus keskittyvät lapsiin, nuoriin ja työikäisiin eli niihin, jotka ovat arvokkaita talouden ja työelämän näkökulmasta. Nykyinen vanhuspolitiikka ja kuntoutuspolitiikka ovatkin pitkälti talouspolitiikkaa,jossa ikääntyneet kansalaiset ovat monenlaisen biopoliittisen puheen ja ohjauksen kohteena: heidän tulee olla terveyttään ja toimintakykyään vaalivia mallikansalaisia. Heidän (siis itse asiassa meidän) ei tulisi rasittaa palvelujärjestelmää eikä tuottaa harmia kansantaloudelle.

Olen ollut kohta 15 vuotta tutkimassa ja kehittämässä ikääntyneiden kuntoutusta.Tänä aikana on tapahtunut paljon eri tieteenaloilla ja kehittämistoiminnassa. Jokainen ikääntyvä sukupolvi luo uudenlaista vanhuutta ja tarvitsee samalla uudenlaisia palveluja. Onko siis ympäröivä maailma rakenteineen ja asenteineen pystynyt uudistumaan riittävästi suhteessa näihin uusiin sukupolviin?

Haim Hazan käyttää gerontologisen autismin käsitettä, jolla hän tarkoittaa yhteiskunnallista ja myös tutkimuksellista sokeutta ja ymmärtämättömyyttä hahmottaa ikääntymistä ilmiönä ja iäkkäitä ainutlaatuisina kansalaisina, osana meitä. Tämä tulee esille siinä, miten erilaisissa poliittisissa ja ohjauksellisissa teksteissä sekä arkisissa tilanteissa käytetty puhe on normatiivista ja luokittelevaa, jossa ikääntyneet asetetaan ulkopuolelle, niiksi toisiksi.
Kuntoutusjärjestelmän tavoin myös aikuiskasvatustiede on suurelta osin ohittanut yli 65-vuotiaat kansalaiset, vaikka vapaa sivistystyö on ollut yksi aikuiskasvatustieteen keskeinen lähtökohta, ja sen suurin osallistujaryhmä ovat olleet juuri ikääntyneet kansalaiset vuosikymmenten ajan. Reilu miljoona yli 65-vuotiasta on ohjaamisen, neuvonnan ja opettamisen kohteena päivittäin eri palvelujärjestelmissä. He toimivat myös itse ohjaajina erilaisissa konteksteissa. Viime vuodelta oleva jatkuvan oppimisen väliraportti jättää kaikki yli 64-vuotiaat suomalaiset kohderyhmänsä ulkopuolelle. Voidaankin kysyä, onko meillä eri alan tutkijoina ja kehittäjinä varaa ohittaa näin suuri joukko kansalaisia. Toisaalta ikääntynyt aikuinen sankarillisena, itseään jatkuvasti haastavana yksilönä on kyllä kiinnostava aikuiskasvatustieteessä esimerkiksi ikääntyvien yliopiston opiskelijana, mutta palvelu- ja avuntarpeita omaavana hän siirtyy sosiaali- ja terveysalan kiinnostuksen kohteeksi.

\section{Tutkimuksen lähtökohdat ja keskeiset käsitteet}

Tutkimukseni perustuu Kelan koordinoimaan ikääntyneiden yhteistoiminnallisen kuntoutuksen tutkimus- ja kehittämishankkeeseen eli IKKU-hankkeeseen. Viisivuotisen hankkeen tavoitteena oli edistää yli 74-vuotiaiden ihmisten kotona asumista kehittämällä gerontologista ryhmämuotoista kuntoutusta Kelan, kuntoutuslaitosten ja hankekuntien yhteistyönä. Hankkeeseen kuuluneen toimintatutkimuksen aikana elin kaikkiaan reilut kolme kuukautta 
kuudessa eri kuntoutusyksikössä ja havainnoin yli 400 yksilö- tai ryhmätilannetta. Hankkeen päättyessä kaikki kokemukseni, nähty ja kuultu, oli yhtenä suurena kysymysmerkkinä mielessäni. Keskeinen kysymys oli: mitä täällä oikein tapahtuu? Hankkeen jälkeisen vuoden kiersin eri sairaanhoitopiireissä kertomassa ikääntyneiden kuntoutuksen perusteista ja hankkeen tuloksista. Tuon kierroksen jälkeen pohdin: miksi ikääntyneiden kuntoutuksesta ei olla kiinnostuneita, vaikka suurin osa erikoissairaanhoidon asiakkaista on ikääntyneitä? Miksi ikääntyneiden kuntoutusta kuvataan huonosti vaikuttavana, vaikka ikääntyneiden kuntoutujien ja kuntoutuksen asiantuntijoiden kertomukset sekä näkemäni tapahtumat olivat mullistavia, ainutlaatuisia, jopa elämänkulun kovia tapahtumia korjaavia, lohduttavia ja toivoa rakentavia. Samanaikaisesti kuntoutus jäi toisille ikääntyneille kohteliaiksi kyläilyiksi kuntoutuslaitoksiin ja asiantuntijoiden työhön perehtymiseksi. Ymmärsin myös, että IKKUhankkeen keskeisiin kysymyksiin toimijuudesta, elämänkulusta, oppimisesta ja ohjaamisesta emme olleet kyenneet vastaamaan riittävästi hankkeen aikana. Näillä ajatuksilla käynnistyi väitöskirjatyöni aikuiskasvatustieteessä toimijuuden jatko-opiskelijaryhmässä.

\section{Oikeus aikuisuuteen}

Miksi olen valinnut tutkimukseni peruskäsitteeksi ikääntynyt aikuinen-käsitteen? Vanhuus on monella tavalla yhteiskunnallisesti määriteltyä ja sopimuksenvaraista. Kuluneen kesän aikana olivat lausuntokierroksilla ikääntyneiden palveluiden uusi laatusuositus ja vanhuspalvelulain uudistusta koskenut taustaraportti. Näissä luonnoksissa ikääntyneet määritellään yksiselitteisesti autettaviksi ja hoidon kohteiksi. Vanhuus sanana liitetäänkin usein sellaisiin käsitteisiin kuin riippuvuus, autettavuus, hauraus, raihnaisuus ja haavoittuvuus. Kuitenkin vain noin 5 prosenttia kaikista yli miljoonasta yli 65-vuotiaasta ikääntyneestä kansalaisesta kuuluu tähän autettavien ja hoidettavien ryhmään, eivätkä nämä käsitteet kuvaa heitäkään kuin vain osittain tai hetkittäin.

Vastakohtana näille määrittelyille ymmärrän ikääntyneen aikuisen aikuisuuttaan jatkavana. Hän on koko elämänsä ajan oppiva, kehittyvä ja toimijuuttaan rakentava yksilö kaikissa elämänsä ympäristöissä. Hän on ainutlaatuinen subjekti, jonka yksilöllistä toimijuutta sellaisenaan ei voi olla kenelläkään toisella. Tämä inhimillinen, eksistentiaalinen olemassaolon oikeutus hänellä on aina, oli hänen toimijuutensa millaista tahansa. Hän ei ole siis kauan elänyt eläkeläinen, diagnooseilla leimattu potilas, fyysisesti mitatut lihakset tai kognitiolla määritellyt aivot. Nämä ovat toki yksittäisiä ominaisuuksia, joilla häntä on arvioitu, kategorisoitu ja normitettu eri konteksteissa, niiden tarpeista lähtien. Tämä normitus toimii kriteerinä ja oikeutena erilaisiin sosiaali- ja terveysalan palveluihin, kuten myös kuntoutukseen.

Minulta on kysytty vuosien varrella toistuvasti, miksi olen kiinnostunut ikääntyneistä ihmisistä. Kysymykseen sisältyy - ainakin ajoittain - piiloinen ajatus siitä, että tämä asiakasryhmä on jotenkin erikoinen, jopa vähempiarvoinen, tuottamaton ja turha. "Mitä heitä kuntouttamaan, kuolevathan he kuitenkin", totesi eräs lääketieteen edustaja aikoinaan minulle. Mutta juuri pitkä elämänkulku ja toimijuus ovat kiinnostavia ikääntyneiden tutkimuksessa ja heidän palvelujensa kehittämisessä. Ja sitä paitsi: Kun lapsuus koko ajan lyhenee ja nuoruus pitenee jatkuen jopa neli- ja viisikymppiseksi saakka, tarvitaan aikuisuudelle tilaa. Miksi aikuisuus ei siis voisi jatkua juuri ikääntyneenä?

\section{Subjektikeskeinen sosiokulttuurinen lähestymistapa toimijuuteen}

Tutkimuksessani hyödynsin aikuiskasvatustieteen subjektikeskeistä sosiokulttuurista lähestymistapaa toimijuuteen. Lähestymistavan pohjalta oletukseni oli, että ikääntyneen aikuisen yksilöllinen toimijuus kuntoutuksessa ilmenee hänen ja kuntoutusrakenteen välisenä vuorovai- 
kutussuhteena. Toimijuutta voivat rajoittaa tai edistää kuntoutusrakenteen sosiokulttuuriset kontekstuaaliset tekijät, kuten kuntoutusympäristön materiaaliset ja ajalliset ehdot, fyysiset ja aineettomat välineet, viralliset ja epäviralliset valtasuhteet, vallitsevat toiminta- ja puhetavat sekä niiden kautta rakentuvat odotukset ja vaatimukset. Subjektikeskeisyyden puolestaan oletin ilmenevän siinä, miten ikääntyneet aikuiset tuovat kuntoutuksessa esille elämänkulkuaan ja nykyistä tilannettaan sekä yksilöllisiä tarpeitaan, tavoitteitaan, valintojaan ja päätöksiään - eli ottavat kantaa suhteessa kuntoutusrakenteen vaatimuksiin ja odotuksiin.

Valitsemani lähestymistapa antoi tutkimukseeni selkeän teoreettisen lähtökohdan ja innostavan soveltamismahdollisuuden. Ensinnäkin, tässä lähestymistavassa määritelty yksilön ja rakenteen vastavuoroisuus ja samalla niiden tarkastelu analyyttisesti erillisinä auttoivat tekemään näkyviksi ikääntyneen aikuisen ja kuntoutusrakenteen suhdetta.

Toiseksi ikääntyneiden kuntoutus perustuu useimmiten lääkinnälliseen kuntoutukseen mutta jää myös määrittelemättä esimerkiksi sosiaali- ja vanhuspalveluissa. Heidän kuntoutuksensa ja sen tutkimus kiinnittyvätkin väistämättä nykyisiin terveysalan rakenteisiin ja niitä ylläpitäviin ja uusintaviin käytänteisiin, niiden käsitejärjestelmiin ja puhetapoihin. Valitsemani aikuiskasvatustieteen lähestymistapa antoikin uudenlaisen, tuoreen näkökulman tarkastella ikääntyneiden kuntoutusta perinteisen kehyksen ulkopuolelta käsin eli toimijuuden näkökulmasta.

Kolmanneksi halusin irrottautua yksilölähtöisestä ja nykyisyyteen kiinnittyvästä kuntoutuskäytännöstä ja pyrkiä ymmärtämään ajallisuuden ja elämänkulun näkökulmia ikääntyneiden kuntoutusarjessa. Samalla saatoin tarkastella heidän vertais- ja kohorttikokemuksiaan. Neljänneksi valitsemani lähestymistapa antoi mahdollisuuden ymmärtää kuntoutusta oppimis- ja muutosprosessina sekä elinikäisen oppimisen yhtenä toimintakenttänä.
Kuntoutus ja kuntoutuminen - rakenteen vai yksilön määrittämää?

Mitä on ikääntyneiden kuntoutus ja kuntoutuminen? Kuntoutuksen uudistamiskomitean kuntoutusmääritelmä vuodelta 2017 näyttäisi painottuvan yhteiskunnallisiin rakenteisiin ja järjestelmiin sekä niiden pohjalta tehtyihin sopimuksiin. Näissä yksilön rooliksi määritellään yksiselitteisesti aktiivisuus. Ikääntyneiden osalta määritelmää voi kuvata normatiiviseksi ja jäykäksi.

Oman näkemykseni mukaan ikääntyneiden kuntoutuksen monitieteiset perusteet, rakenteet ja sisällöt ovatkin vasta muotoutumassa, eikä meillä ole riittävästi monitieteistä tutkittua tai integroitunutta tietoa heidän kuntoutuksensa hyvistä käytännöistä tai vaikuttavuudesta - ei myöskään ikääntyneiden oppimis- ja muutosprosesseista kuntoutuksen aikana. Tutkimukset ovat kohdistuneet rajattuihin diagnoosiryhmiin, kuntoutusprosessien tiettyihin vaiheiseen ja usein myös yksittäisten kuntoutusmenetelmien tutkimuksiin, hyvin laajoista tai erittäin kapeista tulosmuuttujista puhumattakaan. Kun lähtökohtana ovat olleet sairaudet ja toimintakyvyn eri osa-alueet, elämänkulun ja toimijuuden näkökulmat ovat jääneet vähäiselle huomiolle, ellei niitä ole suorastaan ohitettu.

Tällä hetkellä kuntoutusta saa erittäin pieni osa yli 65-vuotiaista kansalaisista, ja sitä toteutetaan pieninä erillisinä siivuina ja hajanaisesti vanhus-, vammais- tai kuntoutussektorilla. Heidän kuntoutustaan ei ole myöskään sisällytetty osaksi laajempia yhteiskunnallisia strategioita. Ikääntyneet saavat siis olla omillaan, näkymättömiä kuntoutuspalvelujen tarvitsijoita.

Emerita professori Aila Järvikoski Lapin yliopistosta kuvaa nykyistä kuntoutustoimintaa edelleen yksilöä hoitavaksi, kasvattavaksi ja sopeuttavaksi toiminnaksi, jossa yksilön ja hänen ympäristönsä muutostarpeita ei ole onnistuttu yhdistämään. Hänen mukaansa kuntoutus jääkin tuloksettomaksi, ellei sitä pystytä toteuttamaan yhteistyössä asiakkaan kanssa, jaetun toimijuuden periaatteella ja yhteisin tavoittein. 


\section{Tutkimuksen tarkoitus ja tutkimus- kysymykset}

Tarkastelin tutkimuksessani ikääntyneiden aikuisten toimijuutta ryhmämuotoisessa kuntoutuksessa subjektikeskeisessä sosiokulttuurisessa viitekehyksessä. Väitöskirjan yhteenveto-osan ylimenevät kolme tutkimuskysymystä olivat:

1) Miten ikääntyneiden aikuisten toimijuus ilmeni kuntoutuksen alussa ja lopussa?

2) Millaisena heidän toimijuutensa näyttäytyi kuntoutustyöntekijöiden puheessa?

3) Millaisia yksilöllisiä ja kontekstuaalisia tekijöitä ilmeni heidän toimijuudessaan?

Tutkimusaineistot koostuivat IKKU-hankkeen toimintatutkimusaineistoista ja niistä valituista harkinnanvaraisista otoksista, joita olivat: käynnistymisvaiheen $(n=11)$ ja päättymisvaiheen $(n=38)$ havainnointiaineistot sekä kuntoutustyöntekijöiden ja tutkijan väliset nauhoitetut fokusryhmäkeskusteluaineistot $(n=6)$. Aineistojen analyysissa hyödynsin laadullista sisällönanalyysia ja diskurssianalyysia.

Ensimmäisen osatutkimukseni tulosten mukaan kuntoutuksen käynnistymisvaiheessa ikääntyneiden toimijuus tuli esille heidän erilaisten aikaorientaatioidensa pohjalta: särkynyt toimijuus kiinnittyi ajattomuuden, jäätynyt toimijuus menneisyyden, käytännöllinen toimijuus nykyisyyden ja transitionaalinen toimijuus elämänkulun aikaorientaatioon. Nykyisyyden aikaorientaatio sekä siihen liittyneet rajatut ja konkreettiset kuntoutustarpeet ja -tavoitteet mahdollistivat kuntoutuksen käynnistämisen etukäteen suunnitellulla tavalla ja aikataululla. Sen sijaan ajattomuuden ja menneisyyden aikaorientaatiota ilmaisseiden kuntoutus käynnistyi hitaasti, koska he kuvasivat kuntoutustarpeitaan niukasti tai hyvin yleisluontoisesti, mutta myös aikaisemman olemassa olleen parhaan mahdollisen toimintakyvyn palautumisen toiveina ja vaatimuksina. Elämänkulun aikaorientaatiota ilmaisseet ikääntyneet toivat esille useita ja erilaisia ta- voitteita, jotka liittyivät kaikkeen mahdolliseen: he halusivat käsitellä menneisyyttä mutta myös nykyisyyden haasteita ja tulevaisuuden toiveita. Kuntoutustavoitteiden selkiyttäminen ja rajaaminen veivät työntekijöiltä aikaa ja sotkivat aikatauluja ja päiväohjelmia.

Toisessa osatutkimuksessa kuntoutuksen päättymisvaiheessa tunnistettiin särkynyt, valikoiva, laajeneva ja uudistunut toimijuus, jotka erosivat toisistaan elämänkulun näkökulmien ja vertaiskokemuksien pohjalta. Kapeimmillaan kuntoutus jäi ikääntyneiden kohteliaiksi vierailuiksi kuntoutuksessa, joka ei koskettanut heidän arkielämäänsä eikä tuottanut vertaiskokemuksia. Laajimmillaan kuntoutusvuosi muodostui koko elämänkulkua koskeneeksi prosessiksi ja vastavuoroisiksi vertaissuhteiksi - kuntoutuksen parhaaksi anniksi ja kokemukseksi, jonka kautta suuntauduttiin toiveikkaasti tulevaisuuteen. Päättymisvaiheen toimijuus antoikin viitteitä siitä, miten kuntoutuksen tuottamat tulokset tulisivat aikanaan siirtymään ikääntyneiden arkeen.

Kolmas osatutkimus kohdistui kuntoutustyöntekijöiden puheeseen ikääntyneistä. Arviointi-, riski- ja ohjauspuhetavoissa ikääntyneet aikuiset ja heidän toimijuutensa kuvattiin pilkottuina ja rajattuina terveyden ja toimintakyvyn osa-alueina. Näiden kautta ikääntyneet nähtiin homogeenisena asiakasryhmänä yhtenevine ongelmineen, ja heidän kuntoutustaan toteutettiin perinteisin työkäytäntein. Sen sijaan toiseus- ja oivalluspuheessa ikääntyneiden toimijuus tuli esille yksilöllisyytenä sekä kuntoutujaryhmän heterogeenisyytenä ja samalla yllätyksellisyytenä: ikääntyneet nähtiin laajemmassa perspektiivissä elämänkulun tapahtumien sekä ympäristötekijöiden kautta rakentuneina ainutlaatuisina yksilöinä. Toiseus- ja oivallispuheessa työntekijät arvioivat kriittisesti myös omaa osaamistaan, työtapojaan sekä kuntoutuskäytäntöjä ja pohtivat työnsä uudistamistarpeita. Juuri nämä työntekijät siirtyivätkin sairaus- ja ongelmakeskeisestä vanhustamispuheesta toimijuutta korostavaan ihmisyyspuheeseen. 
Tutkimustulokset osoittivat, että ikääntyneiden aikuisten toimijuutta kuntoutuksessa voidaan kuvata ja ymmärtää ajallisuuden ja elämänkulun - jotka ovat toimijuuden yksilöllisiä tekijöitä - sekä vertaiskuntoutujien ja työntekijöiden puhetapojen kautta, jotka ovat toimijuuden kontekstuaalisia tekijöitä.

\section{Johtopäätökset}

Tutkimukseni johtopäätöksiä tiivistän muutamaksi nostoksi. Ensimmäiseksi: Jos ikääntyneiden aikuisten toimijuus ymmärretään sosiokulttuurisissa kuntoutusrakenteissa tapahtuvaksi vastavuoroiseksi prosessiksi, on oikeastaan ymmärrettävää, miten ja miksi ikääntyneet asettautuvat eri tavoin kuntoutuksen asiakkaiksi. He tarttuvat eri tavoin kuntoutuksen antamiin tarjoumiin niitä toimijuutensa kautta analyyttisesti hyväksyen, aktiivisesti niitä kieltäen tai niille hiljaa alistuen. Myös tietoinen tekemättä jättämisen toimijuus (ns. omission) on ikääntyneen aikuisen valinta olla kuntoutuksessa.

Toiseksi: Ryhmämuotoisessa kuntoutuksessa ikääntyneillä on kollektiivisen toimijuuden tuottamaa toimijuusvoimaa yhteisen elämänkulun ja nykyisen elämänvaiheen jaettuina kokemuksina. Tätä ei voi olla koskaan heitä nuoremmilla asiantuntijoilla. Kollektiivinen meilmiö (we-ness) mahdollistaa kuntoutujaryhmässä vertais- ja sukupolvikokemusten jakamisen, joiden kautta suuntaudutaan nyt-hetkeen ja myös tulevaisuuteen.

Kolmanneksi: Kuntoutumisen näkeminen ajallisesti etenevänä lineaarisena, kausaalisena ja progressiivisena prosessina ei vastaa ikääntyneiden aikuisten elämänvaiheen erityisyyttä ja sen yllätyksellisyyttä. Kuntoutuminen on temporaalisesti yksilöllinen ilmiö, jossa on hidastumis-, tiivistymis-, pysähtymis- ja taantumisvaiheita, jotka vaativat myös erilaisia ohjaamisen taitoja. Kuntoutusrakenne perustuu kuitenkin lineaariseen kuntoutusinterventioon, joka on useimmiten valmiiksi suunniteltu asiantunti- joiden työnjaon ja työn tekojen sopimus erilaisine ajoituksineen.

Neljänneksi: Kuntoutusrakenteen ymmärtäminen passiivisena suhteessa yksilön aktiivisuuteen on kuntoutuksen sokea piste, unohdettu toimijuuden rakenteellinen osa-alue. Jos ikääntynyt ei sopeudu kuntoutuskäytänteisiin, hänet määritellään motivoitumattomaksi eikä niinkään pohdita sitä, mikä kuntoutusrakenteessa aiheuttaa tällaisen toimijuuden valitsemisen. Jos taas ikääntynyt sopeutuu ja tottuu kuntoutusrakenteeseen tuoden esille asteittain ihan normaalia arkista toimijuuttaan, hän onkin motivoitunut ja kuntoutunut. Onko siis kuntoutusrakenteisiin sopeutuminen ja alistuminen kuntoutumista? Eräänlaiseksi työstettäväksi alistumista?

Kuntoutuspuhe sisältää asiantuntijatyön retoriikkaa, joka uusintaa nykyisiä käytäntöjä ja samalla estää niiden uudistumisen. Kuka jaksaa alituisesti olla arviointi-, riski- ja varoittelupuheen, jopa holhoavan ohjauspuheen kohteena? Toinen puhetapojen ääripää on puolestaan ikääntyneiden kuntoutuksen hienoinen vähättely, eli kun ei oikein tiedä, mitä "näiden" kanssa pitäisi tehdä, ja kun ei tule edistymistä toimintakykymittauksissa, on kuitenkin tehty jotain: on ollut mukavaa, on tarjottu virkistävää tekemistä, sehän piristää... Tuskin nuoremmille aikuisille näillä perusteilla tarjottaisiin kuntoutusta.

Tulevaisuuden ikääntyneillä aikuisilla (eli meillä) tulee olemaan sellaista teoreettista ja käytännöllistä osaamista, jossa eri alojen asiantuntijoiden keskeiseksi ydintehtäväksi jää taitava ohjaus- ja neuvontatyö. Kuntoutuksen ja aikuiskasvatustieteen tuleekin uudistua, jotta voimme edes jossain määrin puhua kuntoutuksen asiakaslähtöisestä toimintakulttuurista tai aikuiskasvatuksesta tieteenalana, joka on kiinnostunut myös ikääntyneistä aikuisista ja heidän kehityskuluistaan ja oppimisprosesseistaan - aikuisuuden pitenevistä työ- ja elämänurista, jotka ovat todella muutakin kuin sosiaali- ja terveysalan sairauskertomuksia tai palvelupäätöksiä. 
Lopuksi: Tutkimustulokseni osoittavat ikääntyneiden aikuisten toimijuuden kuntoutuksessa olevan monimuotoista, mutta myös uskollisuutta omalle itselle ja omalle toimijuudelle kuntoutusrakenteiden paineissa. Kenenkään kohdalla sitä ei voida määritellä heikommaksi tai huonommaksi, ainoastaan erilaiseksi ja yksilölliseksi. Jokainen ikääntynyt itse valitsee ja päättää, mikä on riittävän hyvää toimijuutta hänelle. Myös luopumisen käsittely ja sen hyväksyminen ovat monen ikääntyneen aikuisen keskeisiä tarpeita kuntoutuksessa. Tässä suhteessa sanoudunkin irti toimijuuteen usein liitetystä aktiivisuusparadigmasta.

Käsitteeni toimijuuteen perustuva kuntoutus täydentää perinteistä toimintakykylähtöistä kuntoutusta. Erilaiset elämänkulut ja yksilöllinen toimijuus tulee nähdä resurssina tuottaa

\section{Kirjallisuutta}

Elder GH Jr. Time, human agency, and social change: perspectives on the life course. Soc Psychol Q 1994;57(1):4-15. https://doi.org/10.2307/2786971

Emirbayer M, Mische A. What is agency? Am J Sociol 1998;103(4):962-1023. https://doi.org/10.1086/231294

Eteläpelto A, Vähäsantanen K, Hökkä P, Paloniemi $\mathrm{S}$. What is agency? Conceptualizing professional agency at work. Educ. Res. Rev. 2013;10:4565.https://doi.org/10.1016/j.edurev.2013.05.001

Field J. Lifelong learning, wellfare and mental well-being into older age: trends and policies in Europe. In: Boulton-Lewis G, Tam M, ed. Active ageing, active learning: issues and challenges Dordrecht: Springer Netherlands, 2012:11-20.

Hammell KW. Rethinking rehabilitation's assumptions: challenging "thinking-as-usual" and envisioning a relevant future. In: McPherson $\mathrm{K}$, Gibson GE, Leplege A, ed. Rethinking rehabilitation: theory and practice. Boca Raton: CRC Press, 2015: 66-89.

Hammell KRW, Iwama MK. Well-being and occupational rights: an imperative for critical occupational therapy. Scand J Occup Ther 2012;19(5):385-94.

https://doi.org/10.3109/11038128.2011.611821 vaikuttavia ja toiveikkaita tulevaisuuteen kantavia oppimis-, muutos- ja luopumisprosesseja. Ihmisen oikeus toimijuuteen, oli se millaista tahansa, säilyy niin kauan kuin on elämää, ja ihminen elää niin kauan, kunnes hän kuolee. Tältä pohjalta voin päättää lektioni J. V. Snellmanin sanoihin 1800-luvulta hänen puhuessaan ihmisen oppimisesta: "Ja astuttuaan kerran tämän aidosti elävän oppimisen tielle, hän jättää sen vasta sitten, kun hän jättää elämän”.

\section{Aila Pikkarainen, KT, THM}

aila.pikkarainen@jamk.fi

Aikuiskasvatustieteen alaan kuuluva väitöskirja "Ikääntyneiden aikuisten toimijuus kuntoutuksessa" tarkastettiin 18.09.2020 Jyväskylän yliopistossa.

Hazan H. Gerontological autism: terms of accountability in the cultural study of the category of the Fourth Age. Aging Dis. 2011;31(7):1125-40. https://doi.org/10.1017/S0144686X1100050X

Hitlin S, Elder GH. Time, self, and the curiously abstract concept of agency. Sociol Theory 2007;25(2):170-91. https://doi.org/10.1111/ j.1467-9558.2007.00303.x

Hitlin S, Kirkpatrick Johnson M. Reconceptualizing agency within the life course: the power of looking ahead. Am J Sociol 2015 120(5):1429-72. https://doi.org/10.1086/681216

Jatkuvan oppimisen kehittäminen. Työryhmän väliraportti. Opetus- ja kulttuuriministeriön julkaisuja 19. Helsinki: Opetus- ja kulttuuriministeriö, 2019. Internet:

http://urn.fi/URN:ISBN:978-952-263-641-6 (viitattu 30.10.2020).

Järvikoski A. Monimuotoinen kuntoutus ja sen käsitteet. Sosiaali- ja terveysministeriön raportteja 43. Helsinki: Sosiaali- ja terveysministeriö, 2013.

Lahad K. The linear life-course imperative. In: A table for one: a critical reading of singlehood, gender and time. Manchester: Manchester University Press, 2017. Internet: https://doi.org/10.7765/9781526116352.00005 (viitattu 28.11.2019). 
Marshall VW. Agency, events, and structure at the end of the life course. Adv. Life Course Res. 2005;10:57-91. https://doi.org/10.1016/S1040-2608(05)10002-1

Pikkarainen A. Ikääntyneiden aikuisten toimijuus kuntoutuksessa. JYU Dissertation 262. Jyväskylä: Jyväskylän yliopisto, 2020. Internet: http://urn.fi/URN:ISBN:978-951-39-8250-8 (viitattu 31.9.2020).

Pikkarainen A, Hökkä P, Vähäsantanen K, Paloniemi S, Eteläpelto A. Ikääntyneet aikuiset kuntoutustyöntekijöiden puheessa: työn kohteesta osallistuvaksi aikuiseksi? Aikuiskasvatus 2019; 39(3):194-210.

https://doi.org/10.33336/aik.85709

Pikkarainen A, Koivula R. Monimenetelmällinen lähestymistapa ikääntyneiden kuntoutuksen ja kuntoutumisen tutkimuksessa. Teoksessa: Seppänen-Järvelä R, toim. Monimenetelmällisyys kuntoutuksen tutkimuksessa: havaintoja ja kokemuksia Muutos-hankkeen tutkimuksista. Työpapereita 144. Helsinki: Kela, 2018:31-40. http://urn.fi/URN:NBN:fi-fe2018102438644 (viitattu 29.9.2020).

Pikkarainen A, Koivula R. Ikääntyneiden kuntoutujien, heidän omaistensa ja työntekijöiden näkökulmat IKKU-kuntoutuksen kohdentumisesta, tavoitteellisuudesta, toimivuudesta ja koetusta vaikuttavuudesta: T-IKKU-tutkimushankkeen loppuraportti. Sosiaali- ja terveysturvan raportteja 15. Helsinki: Kela, 2019.
http://urn.fi/URN:NBN:fi-fe201902155050 (viitattu 29.9.2020).

Pikkarainen A, Vaara M, Salmelainen U. Gerontologisen kuntoutuksen toteutus, vaikuttavuus ja tiedon välittyminen. Ikääntyneiden kuntoutujien yhteistoiminnallisen kuntoutuksen tutkimusja kehittämishankkeen loppuraportti. Helsinki: Kela, 2013. http://urn.fi/URN:978-951-669-929-8 (viitattu 30.9.2020).

Pikkarainen A, Vähäsantanen K, Paloniemi S, Eteläpelto A. Older rehabilitees' lifecourse agency in Finnish gerontological rehabilitation. Scand J Occup Ther 2015:22(6):424-34. https://doi.org/10.3109/11038128.2015.1057221

Pikkarainen A, Vähäsantanen K, Paloniemi S, Eteläpelto A. Rehabilitation agency of older adults in group-based intervention. Scand J Occup Ther 2019;26(6):411-22. https://doi.org/10.1080/11038128.2018.1424237

Stone AD, Papadimitrious C. Rehab as an existential, social and learning process: a thought experiment. In: McPherson K, Gibson BE, Leplège A, ed. Rethinking rehabilitation: theory and practice. Boca Raton: CRC Press, 2015:273-90.

Vanhalakka-Ruoho M. Toimijuus elämänkulussa: ohjaustyön perusta? Aikuiskasvatus 2014;34(3): 201-14. http://urn.fi/URN:NBN:fi:ELE-1641110 (viitattu 30.9.2020). 